\title{
The Role of Preschool in Using Gadgets for Digital Natives Generation
}

\author{
Zulkifli $\mathbf{N}^{1}$ \\ Ria Novianti ${ }^{2}$ \\ Meyke Garzia ${ }^{3}$
}

Universitas Riau, Indonesia ${ }^{1,2,3}$

DOI: https://doi.org/10.21009/JPUD.152.02

Accepted: September $15^{\text {th }}$ 2021.Approved: October $4^{\text {th }} 2021$. Published: November $30^{\text {th }}, 2021$

\begin{abstract}
Digital natives' generation is inseparable from gadgets, less socializing, lack of creativity and being an individualist. The digital native's generation wants things that are instant and lack respect for the process. The preoccupation of children with gadgets makes children socially alienated or known as anti-social. Preschool play an important role in the development of the digital native's generation and in the future can help children use gadgets with parents. As it is known, the digital native's generation is a kindergarten child. This study aims to determine the role of preschools in helping the use of gadgets in the digital native generation. This study used a descriptive quantitative approach with simple random sampling technique was obtained 25 kindergarten principals in Pekanbaru City. Data was collected in the form of a questionnaire via google form. Data analysis uses percentages and is presented in the tabular form. The results of the study indicate that the role of preschools in the use of gadgets in digital native generation children in Pekanbaru City is included in the low category. Only a few preschools have organized parenting education for parents. There are almost no rules governing children's use of gadgets at home, and few preschools educate children on how to use gadgets properly. It is expected for teachers and preschools to add special programs in the curriculum to provide information about positive gadget use and parenting programs that discuss digital native generation and collaborate with parents to establish rules such as frequency, duration and content of children using gadgets.
\end{abstract}

Keywords: Digital Native, Preschool, Gadgets

\footnotetext{
${ }^{1}$ Corresponding Author:

Universitas Riau, Indonesia

Email: zulkifli.n@lecturer.unri.ac.id
} 


\section{INTRODUCTION}

The development of digital technology that is happening today makes the inevitable use of technology from everyday life, even already one of the main needs. Various benefits can be processed from technology such as communicating, selling, and buying goods, learning and many other benefits that can now be done online, simply done from where we sit, so practical and easy. However, it turns out that the development of technology in each era causes changes, including childcare. Most parents, both fathers and mothers are so busy at work that they create patterns of interaction and care that rely more on technology. Not only do parents use technology such as gadgets to contact children while at work, either using phone facilities or video calls, but parents also give gadgets to children as a reliable daily learning and play tool. Gadgets are an important device that many people rely on in this millennium era (Yee et al., 2016). Parents give away the device either in the form of a smart phone, tablet, or laptop long before the child can even talk. The goal starts from making children smarter through various educational applications to simply fill the time and provide activities to the child during the father and mother's work. In short, gadgets are becoming such an important device that many people rely on them in this millennium era.

Digital native generation children are in a golden age full of opportunities and hope to shape children into optimal and balanced individuals. Aspects of cognitive, language, moral and religious development, physical and emotional social motor that occurs at this age will be the basis that influences and determines a child's development during adolescence and adulthood. Given the importance of this golden period, it would be great if all the stimulation given to children had a positive impact on a child's development. Digital technology becomes one of the important aspects in invading many stages of child development. Aspects of child development that must adjust the environment that is already based on technology, such as toys, relationships with parents and the surrounding environment (Alia \& Irwansyah, 2018). Gani, (2017) also stated that digital native generation children mastered digital languages very well.

The development of gadgets brings changes not only in adults but also brings changes to children. Several studies show the impact of gadget use in early childhood (Cho \& Lee, 2017). Screen time has been shown to reduce attention span in pre-schoolers. Passive spectacle without interaction with humans has a negative impact (Zivan et al., 2019a). Increased screen time decreases the function of connectivity in the brain associated with the attention ability in children aged 8-12 years. So that, the pattern of brain activity shows reduced attention in children exposed to screens. Speech delays, sleep disturbances, weak social skills and even brain damage, especially in younger children (NAEYC, 2012). Based on research, boys are harder to control than girls when it comes to gadgets, especially when mothers overreact. Therefore, parents need to choose the right approach to be able to apply discipline in the use of gadgets (Morrongiello et al., 2015). Because good parenting practices don't always come naturally in families, parents need 
information that can be their reference in shaping a child's behaviour. In this case, the preschool plays a role to increase parental knowledge through parenting programs.

There is a change in the behaviour patterns of children at preschool. Steiner-Adair and Barker (2013) suggest that teachers share their concerns about the subtle yet pervasive way they see technology affect the preschool experience: four years that want to emulate computer games in the playground and hesitate to play blocks or peruse books. This condition is increasingly found in children today. They would rather play mimicking a game they play on a computer or gadget than play blocks or other games at preschool. If not handled properly, more and more children will experience the negative effects of gadgets. The development of gadget technology that is currently increasing, cannot be avoided, or rejected but how children are given the knowledge and understanding that gadgets have a positive impact on children. If there have been a lot of research and discussion about the use of gadgets in children who connect with parents, this time the use of gadgets will be associated with the role of preschool. Because the role of preschools in this case is significant in child development, PAUD institutions can contribute to address the increasingly alarming problem of gadget use in children.

Therefore, this study aims to find out the extent of the role of preschools in helping the use of gadgets in digital native generation children aged 2-6 years in Pekanbaru city, Riau province. The benefits of the research underlying the results of this study can be a reference to the formation of preschool role instruments in helping the use of gadgets in digital native generation children. This is due to the use of gadgets that cannot be avoided in children of the current digital native generation.

\section{THEORITICAL STUDY}

\subsection{Digital Native's Children}

Digital technology is part of the development of the digital native generation of children. Children who use gadgets show interactions that can influence in changing children's perceptions of intelligence, while at preschool-age children, tend to interpret intelligence as the ability to memorize. Of all the advantages, the digital native generation has a higher risk of mental-health problems. Some of them are anxiety disorders and depression. The digital native generation cannot be separated from gadgets, lacks socialization, is less creative and individualistic. It is dominated by games or watching on YouTube, which is currently a trending topic. Parents tend to give children the opportunity to use the device because it is unavoidable, but there is diversity in duration, content, and utilization in each child. Keeping an eye on a child's connection to gadgets from an early age is important.

The good thing to note about this generation is that they were born into digital environments, technology is already an integral part of their lives. Parents, educators, and other social media have a huge influence in sharing this technology, and the concept of "connection" is nothing more than a central element of this generation. The increasingly 
focused access to technology by children of the "Digital native" generation demonstrates the need for connections between interfaces and technologies that are shifting to the implementation of touch screen devices for more dynamic and natural interactions (Tootell et al., 2014). As the purpose of technological development is to provide good and convenience for human life, of course, devices for children have positive aspects, in the field of improving academic ability by giving children easy access to information. Giving gadgets to children will give children access to a variety of information from social media that is not all in accordance with the stage of development.

In face-to-face encounters, digital natives are said to be less socially proficient and may not have the capacity to apply information (Ransdell et al., 2011). Digital Natives derive their self-esteem from online interactions, where negative feedback can easily destroy a person's self-esteem (Valkenburg et al., 2006). On the one hand, the Internet makes it easy to form superficial bonds in online groups (Allen et al., 2014). On the other hand, it makes the child an obvious target for alienation and exclusion (Allen et al., 2014). When it comes to drinking and drug use among digital natives, the literature is mixed. Young people in some places and countries (such as North America) are expected to live honourably and drink less, whereas digital youth in Europe are expected to drink more (Mueller et al., 2011).

Because of the considerable growth in technology use among children, studies have been done to see how it affects their development (Sharkins et al., 2016). Increased use of technology is linked to an increase in maladaptive and violent behaviour, as well as sleep disorders, obesity, executive function problems, and language and social-emotional delays (Radesky \& Christakis, 2016). However, there has been little research on the effects of technology on the learning and development of sensorimotor abilities required for handwriting (Sheedy et al., 2021). Existing research has had mixed outcomes.

The current debate over educational policy and practice is often based on the assumption that students born in the era of ubiquitous digital media are fundamentally different from previous generations of students. These students have been labelled as "digital natives," with the capacity to digest multiple sources of information at the same time (that is, they can multitask). Teachers, school administrators, politicians/policy makers, and the media perceive they need a completely different approach to education from previous generations because of this mindset. This article provides scientific data showing that a digital native with information skills doesn't exist simply because he or she has never experienced a world without the Internet. This then suggests that one of the characteristics of this generation of students, multitasking, is absent, and that building education around this assumption of capacity is detrimental rather than helpful to learning (Kirschner \& De Bruyckere, 2017). Therefore, digital native children still need intervention to get to know technology, but parental guidance and the role of schools must be on the child's side. 


\subsection{The Role of Preschool in Using Gadget}

Smart phones and tablets, among other media devices, have become commonplace in children's daily life. The great majority of children under the age of eight in the United States $(98 \%)$ have access to a mobile media device (such as a smart phone or tablet) in their families (Rideout \& Robb, 2020). Children from lower-income families spend much more time using screen media than children from higher-income households, despite greater childhood exposure to digital media (Kabali et al., 2015). Although lower-income parents are more likely than higher-income parents to view media as educational (Radesky \& Christakis, 2016), it is unclear if lower-income children's views on media functions differ from those of higher-income children. As a result, the goal of this study was to see if pre-schoolers' perceptions of the functioning of popular media devices differed depending on their family's financial level.

The time children spend using digital devices is increasing rapidly with the development of new and instantly accessible portable technologies, such as smartphones and digital tablets. Furthermore, with the rapid development of gaming media, learning packages, and educational applications for young children, the opportunity to use mobile devices has grown, as children's use time becomes increasingly long (Nielsen Company, 2009; Strasburger et al., 2010; Vandewater et al., 2007). The increasing amount of time children spend on mobile devices has raised concerns about the effects of using digital technology on children's developing health.

Basically, the consequences of the gadget will affect behavior of children in class, children will become difficult to concentrate in learning the things taught by teacher in class, more hyperactive so can't stay still sit down to complete the task given, and the child also feels not comfortable playing with his friends. Although, mostly learning in PAUD involves friends to do activities together in the classroom. All those behaviors are mentioned previously impacted the child's overall mental health.

Preschools and parents have an important role in developing children's understanding of themselves, their environment, and the conditions they face daily. Both have inseparable roles, so that children can reach their full potential, collaboration between preschools and parents must be aligned and supportive of each other. Home education and education in preschools should be consistent. For that, there needs to be communication that can equalize perceptions and rules applied by both parties. An important activity that can be done by preschools to equalize perceptions about children's education and improve parents' understanding of children's education is through parenting education activities. In line with the current conditions where gadgets are the need of most children, one of the most important parenting materials to convey to parents is how to educate children in the digital age.

UNESCO Institute for Statistics (UIS) pays attention to the use of information technology in education related to the level of capacity or national infrastructure (e.g. electricity and internet) to integrate new information technology tools in preschools, the types of information technology that are currently ignored or emphasized with respect to 
usability and affordability, distribution of information technology tools across the country, equalization of the use of information technology by boys and girls, and training for teachers to be able to use information technology in teaching in the classroom. UNESCO recognizes that information technology has an important role to play in expanding access, eliminating exemptions and improving the quality of education (UNESCO, 2014).

The use of gadgets in early childhood aims for entertainment, namely watching cartoon videos, funny children's videos, and other short videos/films. In addition, gadgets are also used to play games. The activities of watching cartoon video. Technology is the main reason parents feel that raising children today is more difficult than in the past (Crouch, 2017). It turns out that technology continues to develop rapidly making children have different characteristics than before, meaning parents need to have the ability to care in accordance with the times, one of which is by learning about the science of parenting or parental education. Information about parenting or parental education can be obtained by parents from various media, such as books, magazines, social media and through workshops and seminars. In this case the preschool also has an obligation as a place of learning for parents. Sylva (1994) argue that a good and effective preschool curriculum should include more than just simple cognitive skills, but other skills that a child has. Thus, the curriculum of early childhood education should not only be able to develop children's cognitive abilities, but also be able to develop various aspects of child development, including character development. The curriculum must also be able to answer the needs of children who change along with the development of technology. One of them is to direct children to use gadgets wisely early on and form positive habits in using gadgets delivered in learning.

Government policy on the use of gadgets in preschools is supported by preschools, where preschools further explain the rules and give doubt if the rules are violated by students, and the principal also cooperates with teachers and parents to supervise and carry out the rules properly. But the policy is very clear and there are still learners who follow the rules by bringing gadgets to preschool, although many learners who use gadgets with positive things such as learning based on technology, but not a few learners use gadgets to play games and other negative things (Kurniawan et al., 2019). A recent survey found that Japan's Ministry of Education, the proportion of children using mobile devices for more than an average of 1 hour per day is $15 \%$ among primary preschool children and 48\% among middle preschool children (National Institute for Educational Policy Research, 2014).

\section{METHOD}

This research uses a quantitative descriptive approach, used to analyze data describing data that has been collected according to actual conditions in the field. 


\subsection{Research Design}

Descriptive analysis is performed to describe and communicate raw data in the form of frequency distribution tables and presented in table form. Research design consists of several stages, including: 1) reference: journals, books, standard procedures; 2) distribution of the questionnaire using google form; 3) data; 4) data analysis; and 5) conclusion. Research design can be seen in figure 1 .

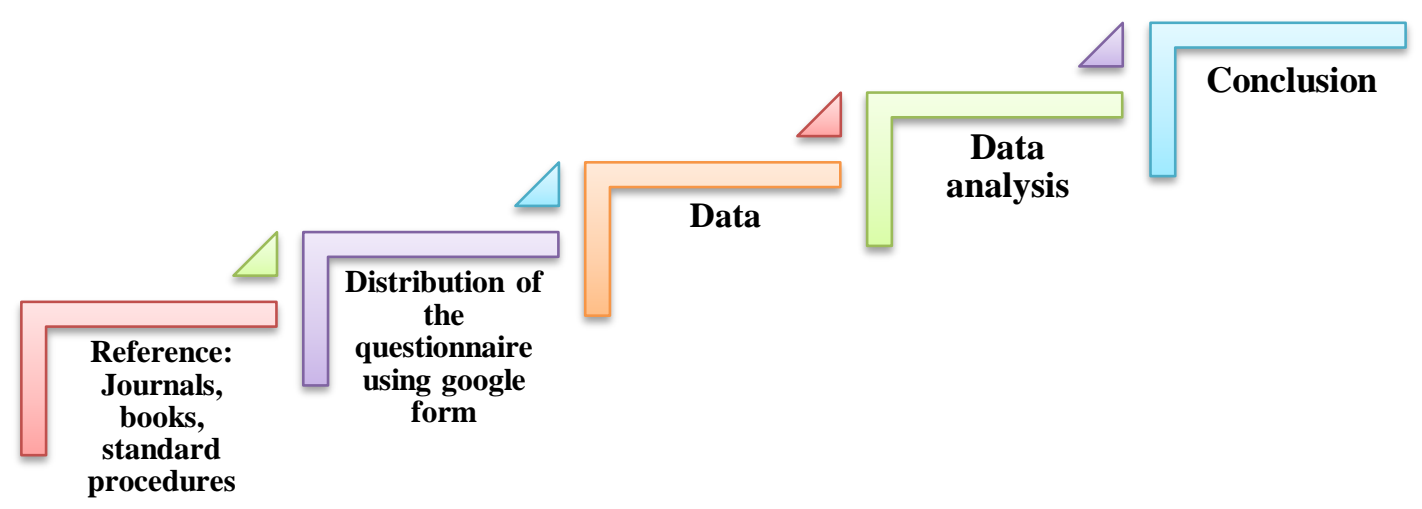

Figure 1. Research Design

\subsection{Location and Time of Research}

The research is in kindergarten in Pekanbaru city of Riau province. The reason the researcher chose the location is: 1) the researcher knows the locations of the study; 2) the location of the study close to where the researcher lives; 3) researchers are familiar with certain informants, so they can easily get the required data. The study was conducted in March 2021.

\subsection{Population dan Sample}

The population in this study is all kindergarten teachers in Pekanbaru City. Population is a generational region consisting of objects / subjects that have certain qualities and characteristics set by the researcher to be studied and then drawn conclusions (Sugiyono, $2017 \mathrm{~b}$ ). The sample in the study was 25 principals. The sampling technique used is simple random sampling, which is the selection sampling of population members is done randomly without looking at strata in the population (Sugiyono, 2017a).

\subsection{Data Collection Techniques}

Data collection techniques are a major step in research because the main purpose of the study is to collect data, if the researcher does not know the data collection technique, then the researcher will not get data that meets the standards. Data collection using questionnaires distributed using google form. The questionnaire will be used as a key data-gathering tool because the research is quantitative. The questionnaire contains statements to respondents using the Likert scale. Researchers used a closed questionnaire by providing a statement with a predetermined number of options. Respondents were asked to choose the option that suited their wishes. 


\subsection{Data Analysis Techniques}

Activities in data analysis are grouping data based on variables and types of respondents, tabulated data based on variables from all respondents, presenting data on each variable studied, performing calculations to answer problem formulations, and performing calculations to test the hypotheses that have been proposed. Data analysis uses percentage's calculation, which provides an overview of the data seen from the average value and percentage. To find out the high or low category of variables, the interpretation of numbers is used (see table 1).

Table 1. Data Interpretation

\begin{tabular}{cc}
\hline Interval & Category \\
\hline $0,00-0,199$ & Very low \\
$0,20-0,399$ & Low \\
$0,40-0,599$ & Currently \\
$0,60-0,799$ & Strong \\
$0,80-1,000$ & Very strong \\
\hline
\end{tabular}

\section{RESULT AND DISCUSSION}

\subsection{Result}

In more detail, it can be considered as a picture of preschool attitudes and knowledge towards the use of gadgets in digital native generation children in Pekanbaru City. Here are the results of the data analysis presented in Table 2 .

Table 2. The Role of Preschools in the Use of Gadgets in Digital native Generation

\begin{tabular}{llccc}
\hline No & Indicator & The mean & \% & Category \\
\hline 1 Parenting program about the use of gadgets for & 0.53 & $53.3 \%$ & Low \\
children & .13 & $13.3 \%$ & Lower \\
2 Apply rules for children to use gadgets at home & 0.40 & $40.0 \%$ & Low \\
3 & $\begin{array}{l}\text { Give children information about using gadget } \\
\text { positively }\end{array}$ & 1,00 & $100.0 \%$ & High \\
4 Rules for teachers to use gadgets during learning hours \\
Average
\end{tabular}

Source: Processed Research Data 2021

Based on Table 2, there are four indicators that measure preschool attitudes and knowledge about the use of gadgets in children. In the indicator of parenting programs using gadgets for children obtained a percentage of $53.3 \%$ is in the low category. Furthermore, the indicator applies the rules for children to use gadgets at home obtained a percentage of $13.3 \%$ with a very low category. On the indicator gives children information about gadget use positively obtained a percentage of $40 \%$ with a low category. In contrast to the three indicators above, in the indicator rules for teachers to use gadgets during learning, hours obtained a percentage of $100 \%$ with a high category. The result obtained averaged 0.34 or with a percentage of $34.4 \%$. This shows that the role of preschools towards the use of devices in digital native generation children in Pekanbaru 
City has a low category. This means that in some preschools that are tasted as a sample of research. The average preschool is less socializing parenting about the use of gadgets for children. Almost and arguably does not apply rules for children in using gadgets at home has not been optimal in providing information to children about the use of positive gadgets and the prohibition of the use of gadgets in learning for teachers.

\subsection{Discussion}

Digital technology has changed the world and as more and more children go online around the world, it is increasingly changing childhood (UNICEF, 2017). Based on the data from the calculations, as many as $13.3 \%$ of preschools that apply the rules for children to use gadgets at home means that there are still some preschools that participate in controlling the use of children's gadgets. It's true that at home the main responsibility for education and parenting lies with parents, but that doesn't mean preschools can't play a role, especially in the use of gadgets that are indeed worrisome. The development of social relationships with peers in the home, preschool, and other contexts is a major achievement in childhood, and these interactions give children the basis for the development of social competence (Guralnick, 1999; Hosokawa \& Katsura, 2018; Coie $\&$ Dodge, 1988). Therefore, frequent use of mobile devices and computers can exacerbate children's social deficits, however, research on the social effects of using media technology has produced mixed results, including its advantages and disadvantages.

Digital technology is an important aspect of the factors that attack many stages of a child's development. Many aspects of a child's development must make adjustments to the already technology-based environment, such as toys, relationships with parents and the surrounding environment (Alia \& Irwansyah, 2018). According to research, screen time has been shown to reduce attention span in pre-school children. Screen stimulus provides visual stimulus and auditory stimulation (Zivan et al., 2019b). In a recent survey, it was found that the average child spends about 7-8 hours on a mobile phone with the maximum time devoted to the Internet, social media, gaming, and SMS (Twenge, 2017). The American Academy of, Pediatrics (2016) have recommended an adequate number of screen age clocks wise for parents to ensure that screen time does not take up scheduled time on academic and health activities.

In addition, it causes speech delays, sleep disturbances, weak social skills and even brain damage, especially in younger children (NAEYC, 2012). Gadget addiction can also affect the development of the child's brain because of excessive production of the hormone dopamine that interferes with the maturity of the prefrontal function of the cortex, namely emotions, self-control, responsibility, decision-making and other moral values (Setianingsih, 2018). Physiologically and psychologically, changes in brain plasticity (or neural networks), cognition, sleep disorders, and obesity, are future problematic trends for the Digital native Gene. Nerve changes due to play and the Internet use in children are particularly sensitive to neural plasticity. This will delay the development of microstructures in cortical brain regions and reduce brain tissue density, leading to deficits in cognition (Takeuchi et al., 2016). Parents and teachers should set 
rules to limit the duration of gadgets used to less than 40 minutes, frequencies less than three times a day and 1-3 days/week to avoid mental-emotional problems in children (Wahyuni et al., 2019).

Parents can't avoid kids from gadgets, but they can help kids by setting rules and supervising their children, so they can have a positive effect on technology (Novianti et al., 2020). In line with the development of technology, the use of gadgets can no longer be avoided and has even become an integral part of our daily lives, therefore, what parents need to pay attention to be the application of rules and assistance in the use of gadgets for their children. With the help of preschools to apply the appropriate rules for the use of gadgets, children can benefit and avoid the negative effects of gadgets. Preschools can provide rules in the form of assessments in the form of checklists regarding the activities of using gadgets at home, related to the time span of use.

Parents see technology as a learning tool, a source of enjoyment and a function of education for children. They are aware of the negative consequences of what it can have on them. Parents understand the advantages and risk factors of digital technology to their children. Most parents see gadgets with functions as a means of learning, entertainment, and education for children, so for this reason, even though children are young most parents give gadgets to children. On the other hand, parents also know the positive and negative impacts of using these gadgets. However, many parents fail to implement the rules of using gadgets at home. There are various negative impacts that can be caused by using gadgets on children (De Lima \& Castronuevo, 2016).

Suhana (2018) concludes that parents need to be transformed into intelligent parenting to have a positive influence on every child. Giving children access to using gadgets for a high duration of time will cause the child to become addicted to gadgets and in the long run can cause problems for the child's emotional development because they will have a lack of social adjustment skills because they do not have enough social skills. Being a generation of intelligent and unique digital native parents requires the ability to apply intelligent parenting in family life. The use of gadgets for a long time intensely will result in the emergence of emotional and behavioral disorders in children. Therefore, the participation of preschools in implementing the rules of use of gadgets is considered increasingly urgent to avoid children from various problems that arise due to the use of gadgets.

Meanwhile, as many as $40 \%$ of respondents consisting of kindergarten principals stated that they provided information to children about the use of gadgets positively. Although preschool through teachers in the classroom has begun to provide understanding to children, but this percentage is relatively low. Communication made by teachers conveyed through conversation, storytelling, or by using media is an effective way to provide understanding to children about the proper use of gadgets. According to Test et al., (2010), whenever adults have a conversation with them, children learn about how others think they learn about their experiences. Then the children compare it to what they think, feel, and do. After this process, children understand that people may think, feel, 
and do things differently. Through conversations with adults in these case teachers, children learn about how others think and experience, then compare it to their own lives. Through this process, the child realizes that others see and experience things differently.

So, if the teacher in the classroom spends time or even has a special program that has been designed in advance to inform about the use of gadgets in a positive way to children, then the child learns that others have different views and opinions (Chapman \& Pellicane, 2014). It is said that parents are required primarily to provide instructions, corrections, and positive modeling to children regarding screen time, although this digital world appears to be the unfamiliar territory. We live in a new era when children are digital natives, and parents are digital immigrants. In other words, children know more about technology than their parents, and it's different from how the world worked hundreds of years ago. By understanding that children's knowledge is better than parents in using gadgets, parents will need the help of various parties to be able to make their children use gadgets proportionally.

All the preschools that were respondents in this study turned out to have applied rules for teachers to use gadgets during study hours. Of course, this is a very appropriate step because the use of gadgets that are not in accordance with their function during learning will interfere with the concentration of children's learning that makes the learning process does not run well. Staring at an electronic screen continuously for a long time causes the child's distress suffering from various problems such as eye irritation or having difficulty focusing for a while. If we face a problem to overcome the screen, imagine how our child's eyes must go through. In this era, we cannot distance ourselves or our children from these devices, so we can try to minimize the impact of these devices on our children (Jonathan \& Andrew, 2016).

The Directorate of Family Education Development of the Ministry of Education and Culture points out that in carrying out partnerships between preschools and parents, parents need to engage in activities in preschools, including taking parenting classes at least twice a year. One of the materials that must be delivered in parenting activities is to educate children in the digital era, parental mediation which can be interpreted as an effort by parents to mediate between children and the use of gadgets (Zaman \& Mifsud, 2017). There are situational factors: weather, family, social contacts, media devices, and home architecture. The related internal factors are behaviour, digital media, health, and parenting. It is not mentioned here that the preschool is a factor associated with this parental mediation process. In fact, adequate literature and research have not been found in the role of preschools in helping the use of gadgets in children.

Whereas a preschool has a great influence on the formation of the concept of knowledge and attitudes of children, in addition to various aspects, cooperation between parents and preschools in solving problems faced by children. In this case, there are already many parents who feel uncomfortable because of the use of gadgets in children. Their children complain and get angry when asked to stop using gadgets, there are late in their language development or unskilled at socializing with others. If the preschool holds 
parenting classes, then this will be a place for parents to share experiences and solve problems. Social interaction with other parents is very important, such as sharing parental topics, but is rarely discussed rather than the topic of child and childbirth (Berlin et al., 2016). So, it is important to consider discussing more about the topic of parenthood and to provide support to parents.

Even though parents are the center educate children because parents know children's habits at home. Twenty-four hours, know the condition of the child even though the child be at preschool. The role of the teacher is also very important. The teacher can accompany and facilitate children to know the world in a good way. Preschools and parents need to master gadgets (smart phones) including existing of applications and content provided on smart phones. There is a lot of inappropriate content for children so that policies and policies from preschools and parents are needed, including the following, do not let children use gadgets in private spaces alone, such as the first point where their use is still assisted by parents and collaboration with the preschool. Make sure the position of the child playing or using the gadget is correct with the right duration and visibility. Do not allow children to use gadgets in the dark and in the sun. When using a smart phone or other personal device, the eyes must be at least 20 inches away from the screen. Do not let children get too close to outdoor Invite children to play outdoors. Facilitate Outdoor play activities for children so that they can distract children from gadgets and play outdoors with pets.

As the National Science Teacher Association kids build an understanding of scientific concepts and processes, apply scientific concepts and technology in everyday life (Martin, 2001), In other words, the teacher must introduce concepts and process technologies that are very close to the child's environment, will easily find ways to solve simple problems in everyday life. When children copy adult behavior, they happen to copy unnecessary and arbitrary behavior, they will also constantly imitate how to use an object (Nielsen, 2012). Although it seems maladaptive, this behavior becomes a way to transmit cultural ideas from one generation to another. In mimicking or mimicking adult behavior, children imitate both positive and negative behaviors without sorting them out. They continue to imitate how to use tools.

So, if the teacher shows discipline not to use gadgets during the study period, this behavior can also be imitated by children in everyday life, that there are times when using and not using gadgets. The results of the study found above, related to the relationship between the role of parents and the use of gadgets by preschool-age children strengthened (Zheng \& Sun, 2021). That shows that the application of social values is a shared responsibility between teachers, communities, preschools, and governments. This means that the role of parents regarding the child's social behavior is indispensable. This is because parents are one of the educational environments in shaping children's social behavior. It is important to understand the impact of technology use on children's brain and body development in the 21 st century with safe and effective use policy guidelines (Novianti \& Garzia, 2020). Schools also play an important role in conducting training for 
parents because there are various works on the topic of mediating the use of digital media for children at home, but there are some limitations. Positive or instructional active family mediation is defined as family members interacting with media content engages the child in a way results in new learning or other positive outcomes are much broader, to include interactions occur both when the child is engaged, and interactions related to the content (Scott, 2021).

\section{CONCLUSION}

This research can be concluded that the role of preschools on the use of gadgets in digital native generation children in Pekanbaru City is in the low category. Most preschools don't have special programs to help kids use gadgets appropriately at home. In addition, although some preschools have conducted parenting programs, they have not specifically discussed the topic of using gadgets for the digital native generation. Born in an era of rapid technology, compared to its parents, gen digital native delivers an exciting combination of opportunities, adventure, and exploration in the future. As such, it is advisable for teachers and preschools to add special programs in the curriculum to provide children with information about positive use of gadgets and parenting programs discussing digital native generation and ways to avoid gadget abuse, as well as working with parents to set rules such as frequency, duration, and content for children.

\section{REFERENCES}

Alia, T., \& Irwansyah, I. (2018). Pendampingan orang tua pada anak usia dini dalam penggunaan teknologi digital [parent mentoring of young children in the use of digital technology]. Polyglot: Jurnal Ilmiah, 14(1), 65-78.

Allen, K. A., Ryan, T., Gray, D. L., McInerney, D. M., \& Waters, L. (2014). Social Media Use and Social Connectedness in Adolescents: The Positives and the Potential Pitfalls. The Australian Educational and Developmental Psychologist, 31(1), 1831. https://doi.org/10.1017/edp.2014.2

Berlin, A., Törnkvist, L., \& Barimani, M. (2016). Content and Presentation of Content in Parental Education Groups in Sweden. The Journal of Perinatal Education, 25(2), 87-96. https://doi.org/10.1891/1058-1243.25.2.87

Chapman, G., \& Pellicane, A. (2014). Growing up social: Raising relational kids in a screen-driven world. Moody Publishers. 
Cho, K.-S., \& Lee, J.-M. (2017). Influence of Smartphone Addiction Proneness of Young Children on Problematic Behaviors and Emotional Intelligence. Comput. Hum. Behav., 66(C), 303-311. https://doi.org/10.1016/j.chb.2016.09.063

Coie, J. D., \& Dodge, K. A. (1988). Multiple sources of data on social behavior and social status in the school: A cross-age comparison. Child Development, 815-829.

Crouch, A. (2017). Tech-Wise Family. Everyday Steps for Putting Technology in Its Proper Place. Baker Books.

De Lima, L., \& Castronuevo, E. (2016). Perception of parents on children's use of gadgets. The Bedan Journal of Psychology, II, 26-34.

Gani, S. A. (2017). Parenting Digital Natives: Cognitive, Emotional, and Social Developmental Challenges.

Guralnick, M. J. (1999). Family and child influences on the peer-related social competence of young children with developmental delays. Mental Retardation and Developmental Disabilities Research Reviews, 5(1), 21-29.

Hosokawa, R., \& Katsura, T. (2018). Association between mobile technology use and child adjustment in early elementary school age. PloS One, 13(7), e0199959.

Jonathan, L. P., \& Andrew, L. F. (2016). Depression in children and adolescents. University of Kansas, Clinical Child Psychology Program.

Kabali, H. K., Irigoyen, M. M., Nunez-Davis, R., Budacki, J. G., Mohanty, S. H., Leister, K. P., \& Bonner, R. L. (2015). Exposure and Use of Mobile Media Devices by Young Children. PEDIATRICS, 136(6), 1044-1050. https://doi.org/10.1542/peds.2015-2151

Kirschner, P. A., \& De Bruyckere, P. (2017). The myths of the digital native and the multitasker. Teaching and Teacher Education, 67, 135-142. https://doi.org/10.1016/j.tate.2017.06.001

Kurniawan, A. R., Chan, F., Sargandi, M., Yolanda, S., Karomah, R., Setianingtyas, W., \& Irani, S. (2019). Kebijakan Sekolah Dalam Penggunaan Gadget di Sekolah 
Dasar [School Policy on the Use of Gadgets in Elementary Schools]. Jurnal Tunas Pendidikan, 2(1), 72-81.

Martin, D. J. (2001). Constructing Early Childhood Science. Delmar Thomson Learning, Inc,

Morrongiello, B. A., McArthur, B. A., Goodman, S., \& Bell, M. M. (2015). Don't touch the gadget because it's hot! Mothers' and children's behavior in the presence of a contrived hazard at home: Implications for supervising children. Journal of Pediatric Psychology, 40 1, 85-95.

Mueller, S., Remaud, H., \& Chabin, Y. (2011). How strong and generalisable is the Generation Y effect? A cross-cultural study for wine. International Journal of Wine Business Research, 23(2), 125-144. https://doi.org/10.1108/17511061111142990

NAEYC. (2012). Technology and interactive media as tools in early childhood programs serving children from birth through age 8.

National Institute for Educational Policy Research. (2014). Zenkoku Gakuryoku Gakusyu Jyokyo Cyosa [Japanese].

Nielsen Company. (2009). Television, Internet, and mobile usage in the U.S.: A2/M2 Three Screen Report. Nielsen Company.

Nielsen, M. (2012). Imitation, pretend play, and childhood: Essential elements in the evolution of human culture? Journal of Comparative Psychology, 126(2), 170181. https://doi.org/10.1037/a0025168

Novianti, R., Febrialismanto, F., Puspitasari, E., \& Hukmi, H. (2020). Meningkatkan pengetahuan orang tua dalam mendidik anak di era digital di Kecamatan Koto Gasib Kabupaten Siak Provinsi Riau [Increasing parental knowledge in educating children in the digital era in Koto Gasib Sub-district, Siak Regency, Riau Province]. Riau Journal of Empowerment, 3(3), 183-190. https://doi.org/10.31258/raje.3.3.183-190 
Novianti, R., \& Garzia, M. (2020). Penggunaan Gadget pada Anak; Tantangan Baru Orang Tua Milenial[Use of Gadgets in Children; Millennial Parents' New Challenge]. Jurnal Obsesi: Jurnal Pendidikan Anak Usia Dini, 4(2), 1000-1010.

Pediatrics, A. A. O. (2016). American Academy of Paediatrics announces new recommendations for children's media use. Advocacy \& Policy.

Radesky, J. S., \& Christakis, D. A. (2016). Increased Screen Time: Implications for Early Childhood Development and Behaviour. Paediatric Clinics of North America, 63(5), 827-839. https://doi.org/10.1016/j.pcl.2016.06.006

Ransdell, S., Kent, B., Gaillard-Kenney, S., \& Long, J. (2011). Digital immigrants fare better than digital natives due to social reliance: Digital immigrants and social reliance. British Journal of Educational Technology, 42(6), 931-938. https://doi.org/10.1111/j.1467-8535.2010.01137.x

Rideout, V., \&. Robb, M. B., \& Robb, M. B. (2020). The commonsense census: Media use by kids aged zero to eight. Common Sense Media.

Scott, F. L. (2021). Family mediation of preschool children's digital media practices at home. Learning, Media, and Technology, 1-16. https://doi.org/10.1080/17439884.2021.1960859

Setianingsih, S. (2018). Dampak penggunaan gadget pada anak usia prasekolah dapat meningkatan resiko gangguan pemusatan perhatian dan hiperaktivitas [The impact of using gadgets on preschool-aged children can increase the risk of attention deficit disorder and hyperactivity]. Gaster, 16(2), 191-205.

Sharkins, K. A., Newton, A. B., Albaiz, N. E. A., \& Ernest, J. M. (2016). Preschool Children's Exposure to Media, Technology, and Screen Time: Perspectives of Caregivers from Three Early Childcare Settings. Early Childhood Education Journal, 44(5), 437-444. https://doi.org/10.1007/s10643-015-0732-3

Sheedy, A. J., Brent, J., Dally, K., Ray, K., \& Lane, A. E. (2021). Handwriting Readiness among Digital Native Kindergarten Students. Physical \& Occupational Therapy In Pediatrics, 41(6), 655-669. https://doi.org/10.1080/01942638.2021.1912247 
Steiner-Adair, C., \& Barker, T. H. (2013). The Big Disconnect (1st ed.). Harper Collins.

Strasburger, V. C., Jordan, A. B., \& Donnerstein, E. (2010). Health effects of media on children and adolescents. Pediatrics, 125(4), 756-767.

Sugiyono. (2017a). Statistika untuk Penelitian[Statistics for Research]. Alfabeta.

Sugiyono, P. (2017b). Metode Penelitian Pendidikan: Pendekatan Kuantitatif, Kualitatif, R\&D [Educational Research Methods: Quantitative, Qualitative, R\&D Approach]. Cetakan Ke-25. Bandung: CV Alfabeta.

Suhana, M. (2018). Influence of Gadget Usage on Children's Social-Emotional Development. 169(Icece 2017), 224-227. https://doi.org/10.2991/icece17.2018 .58

Sylva, K. (1994). School Influences on Children's Development. Journal of Child Psychology and Psychiatry, 35(1), 135-170. https://doi.org/10.1111/j.14697610.1994.tb01135.x

Takeuchi, H., Taki, Y., Hashizume, H., Asano, K., Asano, M., Sassa, Y., Yokota, S., Kotozaki, Y., Nouchi, R., \& Kawashima, R. (2016). Impact of videogame play on the brain's microstructural properties: Cross-sectional and longitudinal analyses. Molecular Psychiatry, 21(12), 1781-1789.

Test, J. E., Cunningham, D. D., \& Lee, A. C. (2010). Talking With Young Children: How Teachers Encourage Learning. Dimensions of Early Childhood, 38(3), 3-14.

Tootell, H., Freeman, M., \& Freeman, A. (2014). Generation Alpha at the Intersection of Technology, Play and Motivation. 2014 47th Hawaii International Conference on System Sciences, 82-90. https://doi.org/10.1109/HICSS.2014.19

Twenge, J. M. (2017). IGen: Why today's super-connected kids are growing up less rebellious, more tolerant, less happy-And completely unprepared for adulthood-And what that means for the rest of us. Simon and Schuster.

UNESCO. (2014). Information and Communication Technology (ICT) In Education in Asia. Information Papers, 6(22), 6. 
UNICEF. (2017). UNICEF for Every Child. The State of The World's Children 2017. Children in a Digital World.

Valkenburg, P. M., Peter, J., \& Schouten, A. P. (2006). Friend Networking Sites and Their Relationship to Adolescents' Well-Being and Social Self-Esteem. CyberPsychology \& Behavior, $\quad 9(5), \quad$ 584-590. https://doi.org/10.1089/cpb.2006.9.584

Vandewater, E. A., Rideout, V. J., Wartella, E. A., Huang, X., Lee, J. H., \& Shim, M. (2007). Digital childhood: Electronic media and technology use among infants, toddlers, and preschoolers. Pediatrics, 119(5), e1006-e1015.

Wahyuni, A. S., Siahaan, F. B., Arfa, M., Alona, I., \& Nerdy, N. (2019). The Relationship between the Duration of Playing Gadget and Mental Emotional State of Elementary School Students. 7(1), 148-151.

Yee, H. K., Seok, C. B., Hashmi, S. I., Teng, T. L., \& Indran, R. (2016). Why Gadget Usage Among Pre-schoolers Should Matter to Teachers? A Pilot Study. GESJ: Education Science and Psychology, 40(3), 14.

Zaman, B., \& Mifsud, C. L. (2017). Editorial: Young children's use of digital media and parental mediation. Cyberpsychology, 11(3 Special Issue), 9. https://doi.org/10.5817/CP2017-3-xx

Zheng, P., \& Sun, J. (2021). Preschool Children's Use of Digital Devices and Early Development in Hong Kong: The Role of Family Socioeconomic Status. Early Education and Development, 1-19. https://doi.org/10.1080/10409289.2021.1920767

Zivan, M., Bar, S., Jing, X., Hutton, J., Farah, R., \& Horowitz-Kraus, T. (2019a). Screenexposure and altered brain activation related to attention in preschool children: An EEG study. Trends in Neuroscience and Education, 17, 100117. https://doi.org/10.1016/j.tine.2019.100117 
Zivan, M., Bar, S., Jing, X., Hutton, J., Farah, R., \& Horowitz-Kraus, T. (2019b). Screenexposure and altered brain activation related to attention in preschool children: An EEG study. Trends in Neuroscience and Education, 17, 100117. 